\title{
ANTAL MIKLÓS: ANATÓMIAI, SZÖVET- ÉS FEJLŐDÉSTANI INTÉZET, 1921-2018 - AZ OKTATÁS, A NEVELÉS ÉS A TUDOMÁNY SZOLGÁLATÁBAN A DEBRECENI EGYETEMEN
}

\author{
Debreceni Egyetemi Kiadó, [Debrecen], [2018.] 44 lap
}

A Debreceni Egyetem Általános Orvostudományi Karának százéves évfordulója alkalmából a Kenézy Villában 2018 októberében-novemberében négyrészes intézettörténeti előadássorozat keretében emlékeztek egykori és jelenlegi egységvezetők intézetük/ klinikájuk történetére.

Az első szimpózium 2018. október 17-én került megrendezésre, amelynek legelső előadása volt Antal Miklós professzor, az Anatómiai, Szövet- és Fejlődéstani Intézet volt igazgatójának részletes és színvonalas bemutatása intézetének elmúlt majdnem száz évéről. Ennek az előadásnak szerkesztett, letisztázott és átnézett változata jelent meg könyv formában a Debreceni Egyetemi Kiadónál.

Az Anatómiai, Szövet- és Fejlődéstani Intézet történetének kutatása komoly előzményekre tekint vissza. Földes István professzor, az intézet legidősebb tagja és egyben az Általános Orvostudományi Kar doyenje 2009-ben terjedelmes monográfiában dolgozta fel az intézet történetét. ${ }^{1}$ Erről a kötetről Szállási Árpád orvostörténész recenziója éppen a Gerundium legelső számában jelent meg. ${ }^{2}$

Antal Miklós összefoglalása nemcsak elkülöníti az intézet történetének egyes szakaszait a meghatározó igazgatók szerint (Huzella Tivadar 1921-1932, Jankovich László 1934-1944, Törő Imre 1945-1950, Krompecher István 1950-1975, Székely György 1975-1994, Antal Miklós 1994-2016, Szücs Péter 2016-), hanem azokon belül külön elemzi a kutatás és az oktatás korabeli irányvonalait és feltételeit. Külön kiemeli, mennyire volt vagy volt nem éles váltás egy új intézetigazgató professzor kinevezése az addigi munkához képest (pl. az a kényszerhelyzet, amikor 1934-ben - két évnyi betöltetlen poszt után - a szegedi törvényszéki orvos Jankovich Lászlót helyezték ide az intézet élére, aki beletanult új pozíciójába és becsülettel ellátta, $s$ lehetőség szerint még fejlesztette is az intézetet).

\footnotetext{
${ }^{1}$ Földes István, A Debreceni Egyetem Orvos-és Egészségtudományi Centrum Anatómia, Szövet-és Fejlödéstani Intézetének története, A debreceni orvosképzés nagy alakjai 23. (Debrecen: Debreceni Egyetem Orvos- és Egészségügyi Centrum, 2009), 288.

2 Gerundium - Egyetemtörténeti Közlemények 1, 1. sz. (2010): 155-158.
} 
A harmincas évek elitista, kis látszámú felsőoktatása már rég a múlté és a szovjet típusú tömeg-felsőoktatás sem maradhatott ugyanúgy. A rendszerváltás óta eltelt három évtized természetesen óriási változásokat hozott a technikai fejlődésben és a hallgatók létszáma és összetétele is jelentősen megváltozott. Az általános orvosok mellett 1977 től az önállóvá vált fogorvosképzés számára is oktatni kellett az anatómiát, valamint 1987-től megindult az angol nyelvü orvosképzés is, amely révén a külföldi hallgatók létszáma évről-évre folyton nőtt és jelenleg is nő.

A gyorsuló technikai fejlödés nemcsak a kutatás eszközeit forradalmasította, hanem az egyetemi oktatásban és vizsgáztatásban is jelentős változásokat hozott (audivizualis technikák, a számítógép és az internet felshasználása). Ezeknek a változásaknak döntő része a szerző igazgatósága alatt következett be, így testközelből ismerhette ezeket a folyamatokat, és így tudta dokumentálni a fejlődés és a bővülés részleteit.

A tetszetős kiadványt fekete-fehér archív és színes jelenkori fényképek teszik változatosabbá, szemléletes képet nyújtva arról, hogy az Anatómiai, Szövet- és Fejlödéstani Intézet milyen utat járt be az utóbbi majdnem száz év során.

Mudrák József

${ }^{3}$ Huzella az alapításkor 60 fóben (!) határozta meg az anatómiai oktatásban részesíthető hallgatók (és ezáltal a felvehető elsőévesek) számát, és ehhez ő és közvetlen utódai ragaszkodtak is. 